\title{
Implementasi Kebijakan Pemilihan Kepala Pemerintahan Negeri di Kecamatan Salahutu Kabupaten Maluku Tengah
}

\author{
Implementation of the Election of Head of State \\ Administration in Kecamatan Salahutu, Central Maluku \\ District
}

\author{
M. Husein Maruapey*, Budiman Rusli, Nina Karlina \& Mudiyati Rahmatunnissa \\ Pascasarjana Administrasi Publik, Fakultas Ilmu Sosial dan Ilmu Politik \\ Universitas Padjadjaran, Indonesia.
}

\begin{abstract}
Abstrak
Penelitian Tentang Implementasi Kebijakan Pemilihan Kepala Pemerintahan Negeri di Kabupaten Maluku Tengah (Studi Di Kecamatan Salahutu) Belum efektif pelaksanaannya walaupun Kebijakan Peraturan Daerah Nomor 3 Tahun 2006 telah berlangsung lama. Pemerintah Daerah Kabupaten Maluku Tengah telah melakukan berbagai terobosan, namun terkendala dengan berbagai permasalahan. Permasalahn konflik internal diantara Matarumah Parentah serta intrik dan kepentingan dari Elit Politik Lokal. Metode Penelitian yang digunakan adalah Metode Kualitatif. Hal ini dikarenakan objek yang diteliti memerlukan pengamatan langsung dari peneliti sebagai instrumen utama sekaligus menghindari terjadinya spekulasi dan rekayasa data atas masalah penelitian. Berdasarkan penelitian, menunjukan ketidakefektifan pemilihan Kepala Pemerintahan Negeri disebabkan Personil atau Sumberdaya Saniri Negeri belum mumpuni, tidak konsisten dengan aturan, kebijakan yang setengah hati dan tidak tegas, kondisi eksternal masyarakat yang terpolarisasi dengan kebijakan Orde Baru. Implementasi Kebijakan Pemilihan Kepala Pemerintahan Negeri di Kecamatan Salahutu belum efektif dilaksanakan karena , variabel (1) Idealized Policy,(2) Implementation Organization,(3)Target Group, dan (4) Environmental Factors tidak dilakukan secara baik oleh Saniri Negeri dan badan pelaksana lainnya.

Kata Kunci: Implementasi Kebijakan, Peraturan Daerah, Kepala Pemerintahan Negeri.
\end{abstract}

\begin{abstract}
Research on the Implementation of Village Election Central Maluku Regency (Studi in Salahutu Sub District) Not yet effective implementation although the Policy of Regional Regulation Number 3 Year 2006 has been going on for a long time. The Local Government of Central Maluku Regency has made various breakthroughs, but is constrained by various problems. such as the Internal Conflict between Parentah Matarumah and the intrigue and interests of the Local Political Elite. The research method used is Qualitative Method. This is because the object under study requires direct observation from the researcher as the main instrument while avoiding the occurrence of speculation and data engineering on research problems. Based on the research, the ineffectiveness of the Village election was caused by: Personnel or State Saniri Resources not yet qualified, inconsistent with rules, halfhearted and unequivocal policies, external conditions of the community polarized with New Order policies. Implementation of Village Election in Salahutu Sub District has not been effectively implemented because the variables (1) Idealized Policy, (2) Implementation Organization, (3) Target Group, and (4) Environmental Factors are not done well by Saniri Negeri and other implementing agencies.
\end{abstract}

Keywords: Policy Implementation, Local Regulation, Head of State Administration.

How to Cite: Maruapey, M.H. Rusli, B. Karlina, N. \& Rahmatunnissa, M. (2018). Implementasi Kebijakan Pemilihan Kepala Pemerintahan Negeri di Kecamatan Salahutu Kabupaten Maluku Tengah. JPPUMA: Jurnal Ilmu Pemerintahan dan Sosial Politik UMA, 6 (1): 68-75.

*Corresponding author:

ISSN 2549-166o (Print)

E-mail: maruapey.husein@gmail.com

ISSN 2550-1305 (Online) 


\section{PENDAHULUAN}

Berlakunya UU Nomor 6 Tahun 2014 tentang Desa memberikan semangat baru bagi masyarakat di Desa yang selama ini menjadi penonton dalam pembangunan di Daerah. Masyarakat diberikan kewenangan pengakuan terhadap hak asal usul (Rekognisi).

Masyarakat Kabupaten Maluku Tengah merupakan masyarakat adat, dikenal sebagai satu kesatuan masyarakat hukum adat dengan nama Negeri berdasarkan hukum adat setempat. Kesatuan masyarakat adat beserta perangkat Pemerintahannya sudah sejak lama hidup dan berkembang serta dipertahankan dalam tatanan pergaulan hidup masyarakat. Negeri-Negeri di propinsi Maluku, khususnya Negeri di Kabupaten Maluku Tengah memiliki kewenangan untuk mengatur dan mengurus kepentingan masyarakat setempat berdasarkan hak asal usul Negeri, adat istiadat dan hukum adat yang diakui dalam Sistem Pemerintahan Nasional.

Sejalan dengan konsep penataan desa sebagaimana tertuang dalam amanat UU No 6 tahun 2014 tentang Desa, Pemerintah Daerah Maluku sangat mengapresiasi dengan melakukan penataan Desa Adat dan Desa Administratif serta menginventarisir dan mengidentifikasi adat istiadat dan budaya lokal masyarakat Maluku.

Sehubungan dengan itu Pemerintah Daerah Maluku saat ini sedang menyusun pedoman umum yang dapat menjadi dasar serta acuan untuk menetapkan Desa dalam Peraturan Daerah Kabupaten/Kota.
Untuk itu Pemerintah Daerah Kabupaten Maluku Tengah menerbitkan Peraturan Daerah (Perda) Nomor 03 tahun 2006 tentang Tata Cara Penetapan dan Pemilihan Kepala Pemerintah Negeri. Peraturan Daerah ini, dimaksudkan untuk melaksanakan prinsip demokrasi dalam tatanan Pemerintahan Adat, terutama aplikasinya terhadap mekanisme pencalonan, pemilihan dan pelantikan Kepala Pemerintah Negeri, sehingga dapat melahirkan figur pemimpin yang menghargai hak masyarakat adat, sebagai bagian dari hak asasi manusia, tanpa mengabaikan prinsip-prinsip hukum adat maupun peraturan perundangundangan yang berlaku.

$$
\text { Dari berbagai ketentuan tentang }
$$
prosedur memilih dan dipilih sebagai Kepala Desa atau Kepala Pemerintahan Negeri, di Kecamatan Salahutu Kabupaten Maluku Tengah, peneliti menjumpai adanya kesenjangan dan permasalahan secara prosedural, terkait implementasi Perda Nomor 3 Tahun 2006.

Permasalahan tersebut antara lain:

1. Adanya keresahan di tengah masyarakat sehubungan dengan penjaringan dan penentuan calon Raja, ansih hanya kepada warga tertentu di tengah masyarakat Adat. Semua Anak Negeri yang semula memiliki peluang menjadi Raja atau Pemimpin Negeri harus tersingkir lantaran bukan berasal dari Matarumah Parentah yang secara adat tidak dimungkinkan untuk berkompetisi menjadi orang nomor satu di Negerinya. 
2. Di Kecamatan Salahutu Kabupaten Maluku Tengah, seluruh Desa Adat belum menerbitkan Peraturan Negeri sebagai penjabaran dari Perda Nomor 3 Tahun 2006.

3. Ada beberapa diantara Negeri masih mencari formulasi yang baik agar tidak menimbulkan gejolak dalam pelaksanaan Perneg tersebut.

4. Persyaratan calon Kepala Pemerintah Negeri, selain ketentuan umum, panitia pemilihan juga menetapkan persyaratan diluar ketentuan dan persyaratan sebagaimana terdapat dalam Peraturan Negeri, misalnya saja di Desa Tulehu panitia mencantumkan persyaratan "calon Kepala Desa harus rajin menjalankan Sholat lima waktu dengan telah menyelesaikan khatam Qur'an, serta harus bersedia disumpah didepan masyarakat adat terkait dengan silsilah keturunan mahkota penerus Raja atau Kepala Pemerintahan Negeri.

5. Banyak intrik dan kepentingan elit politik lokal, baik pada legislatif maupun eksekutif.

6. Terdapat lebih dari satu Matarumah Parentah (ahli Waris Raja) yang menyebabkan terjadinya konflik internal, misalnya Pemilihan Kepala Pemerintahan Negeri di Negeri Tengah-Tengah Kecamatan Salahutu Kabupaten Maluku Tengah tahun 2011 ditandai dengan konflik internal diantara Soa atau Matarumah Parentah Tuharea Atas dan Tuharea Bawah.
7. Diterbitkannya UU Nomor 6 Tahun 2014 dengan dana Desa yang menggiurkan hingga 1 Milyar setiap Desa, disinyalir sebagai pangkal permasalahan konflik Soa atau Matarumah Parentah di Kabupaten Maluku Tengah.

Dari beberapa permasalahan yang disampaikan, peneliti melihat bahwa Implementasi Kebijakan Pemilihan Kepala Pemerintahan Negeri di Kecamatan Salahutu Kabupaten Maluku Tengah memperlihatkan ketidakefektifan dalam penerapannya. Oleh karena itu menjadi menarik bagi peneliti, untuk melakukan kajian mengapa Implementasi Kebijakan Pemilihan Kepala Pemerintah Negeri di Kecamatan Salahutu Kabupaten Maluku Tengah belum efektif dalam penerapannya.

\section{METODE PENELITIAN}

Objek penelitian ini adalah "Implementasi Kebijakan Pemilihan Kepala Pemerintahan Negeri Di Kabupaten Maluku Tengah" (Studi di Kecamatan Salahutu) menggunakan pendekatan kualitatif. Sebagaimana diungkapkan beberapa ahli, metode penelitian kualitatif ini sangat bergantung pada pengamatan mendalam terhadap perilaku manusia dan lingkungannya (Bogdan (1982), Miles And Huberman (1984), Brannen (2005)). Pemilihan metode ini karena objek yang diteliti memerlukan pengamatan langsung dari peneliti sebagai instrumen utama dari penelitian untuk mengkaji proses dan makna. 
Untuk mendapatkan data dan informasi peneliti melakukan pengamatan atau observasi langsung dengan wawancara mendalam (indepth interview) yang direkam kepada informan yang dianggap menegtahui permaslahan. Selain itu catatan lapangan juga digunakan untuk menuliskan kembali apa yang disampaikan informan tentang hal yang berkaitan dengan pengamatan.

\section{HASIL DAN PEMBAHASAN}

\section{Kondisi Umum Wilayah Penelitian}

Kecamatan Salahutu dengan Ibukotanya Tulehu merupakan salah satu Kecamatan dari 17 Kecamatan yang terdapat di Kabupaten Maluku Tengah.Luas wilayah Kecamatan Salahutu keseluruhannya adalah kurang lebih $151.082 \mathrm{Km}^{2}$.

Secara geografis Wilayah Kecamatan Salahutu terletak pada $3,15^{\circ}-3,40^{\circ}$ Lintang Selatan dan $126,30^{\circ}-127^{\circ}$ Bujur Timur dengan batas-batas wilayah sebagai berikut : sebelah Selatan dengan Teluk Ambon Baguala (Kali Waitatiri); Sebeleh Utara dengan Selat Seram; sebelah Timur dengan Selat Haruku; sebelah Barat dengan Leihitu (Morela/Kali Tomol)

Secara administratif Kecamatan Salahutu terdiri dari 6 Desa atau lebih dikenal dengan sebutan Negeri oleh masyarakat setempat diantaranya: Negeri Suli; Negeri Tial; Negeri Tengah-Tengah; Negeri Tulehu; Negeri Waai; Dan Negeri Liang.

Dari keenam Negeri yang terdapat di Kecamatan Salahutu, dua diantaranya pemeluk agama Nasrani yakni Negeri Suli dan Negeri Waai. Komunikasi antar masyarakat adat di dua Negeri Adat inipun menggunakan bahasa Indonesia karena tidak memiliki bahasa tanah sebagaimana empat Negeri lainnya yang dalam kesehariannya menggunakan bahasa tanah dan bahasa Indonesia sebagai bahasa pergaulan dan komunikasi dalam interaksi sehari hari.

Kondisi Negeri-Negeri di Kecamatan Salahutu tersebar di pesisir pantai, hal inilah yang menyebabkan masyarakat setempat cenderung berprofesi sebagai nelayan, selain profesi lain seperti Pegawai Negeri, Pedagang, Petani, Buruh dan lain lain.

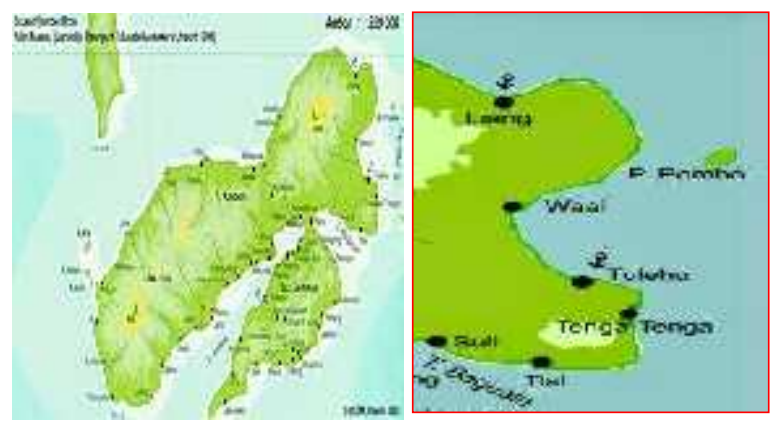

Gambar : Peta Wilayah Kecamatan Salahutu Sumber : Kantor Kecamatan Salahutu

Untuk mengetahui luas wilayah Kecamatan Salahutu secara keseluruhan dapat dilihat dalam Grafik sebagai berikut :

Grafik .1. Luas Wilayah Kecamatan Salahutu

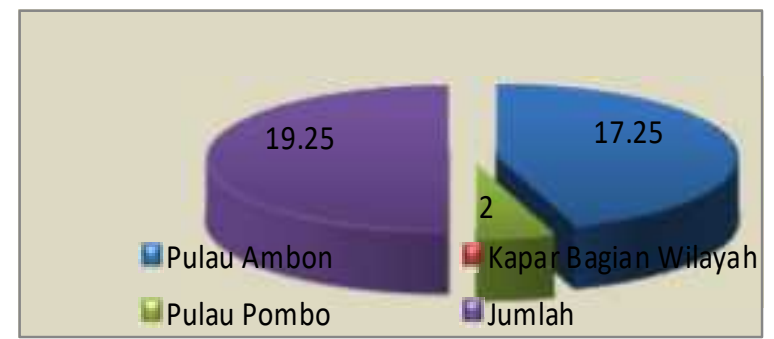

Sumber : Kantor Kecamatan Salahutu

Grafik di atas menunjukan bahwa, luas seluruh wilayah Kecamatan Salahutu terdapat di Pulau Ambon dengan presentasi sebesar 
89.5\%, sedangkan $10,5 \%$ hanya berada di Pulau Pombo.

Faktor Faktor Yang Menyebabkan

Ketidakefektifan Pelaksanaan Pemilihan

Kepala Pemerintahan Negeri/Raja di Kecamatan Salahutu

Beberapa faktor penyebab

ketidakefektifan pelaksanaan pemilihan Raja

di Kecamatan Salahutu dirumuskan oleh peneliti sebagai berikut :

1. Personil /SDM yang Tidak Sesuai dengan Persyaratan.

Dari penelitian yang dilakukan oleh peneliti hingga dirampungkannya penelitian, sebagian dari Negeri-Negeri belum menerbitkan Perneg sebagai petunjuk teknis pelaksanaan Perda Nomor 3 Tahun 2006. Salah satu Indikator dari Variabel Implementing Organization menurut Smith adalah Struktur dan personil (SDM) yang tidak sesuai dengan persyaratan. Dari penelusuran yang dilakukan, bahwa yang menjadi penghambat pelaksanaan pemilihan Raja salah satunya adalah belum dirampungkannya Perneg oleh karena ketidakmampuan badan badan pelaksana (Saniri Negeri) dari aspek personil atau Sumber Daya Manusia dalam melaksanakan sebuah program Pemerintah.

Yang tak kalah peliknya adalah Polemik diantara Matarumah Parentah. Kendala inilah yang membuat proses pelaksanaan pemilihan Raja menjadi terhambat termasuk beberapa kegiatan Pemerintahan Negeri.

Terkait dengan implementasi kebijakan, Edward III (1980) sebagaimana dikutip Rusli (2015) bahwa Implementasi Kebijakan merupakan sesuatu yang sangat kompleks dengan berbagai faktor yang mempengaruhi keberhasilan implementasi kebijakan. Menurut Edward III selain Sumberdaya, maka faktor lain seperti komunikasi, Sikap Pelaksana dan Struktur Birokrasi adalah juga merupakan empat faktor yang sangat mempengaruhi implementasi kebijakan.

2. Ketidak Konsistenan Saniri Negeri dengan Aturan.

Dalam pandangan Smith bahwa implementasi kebijakan publik harus memenuhi kebijakan formal seperti apa yang dilaksanakan, keputusan formal atau undangundang. Dalam penelitian, Peneliti menjumpai penyebab ketidakefektifan pelaksanaan pemilihan Kepala Pemerintahan Negeri, satu diantaranya adalah ketidak konsistenan terhadap aturan sebagai satu kebijakan formal yang harus menjadi pedoman hukum Saniri Negeri.

3. Kebijakan yang Setengah Hati/Tidak Tegas dan Hanya kepada Golongan Tertentu.

Layaknya produk kebijakan itu mengedepankan aspirasi masyarakat sebagai orang yang langsung terkena dampak kebijakan tersebut.Dan tidak mendudukan masyarakat sebagai objek semata. Sangat mengerikan apabila produk kebijakan hanya diperuntuk buat segelintir orang apalagi jika kebijakan tersebut diperuntukan kepada kepentingan elit politik dan melanggengkan kekuasan birokrasi. Kebijakan publik semestinya dipahami sebagai sebuah kebutuhan untuk mengatur tata kehidupan bermasyarakat. Maka seharusnya kebijakan 
tersebut harus melindungi hak dan kewajiban setiap warga negara.

4. Kondisi Eksternal Masyarakat yang Telah Terpolarisasi dengan Kebijakan Orde Baru.

Penyebab terjadinya ketidakefektifan pelakanaan pemilihan Raja di Kecamatan Salahutu salah satunya disebabkan adanya kondisi masyarakat adat yang telah terpolarisasi dengan sistem pemilihan demokrasi moderen dimana setiap orang berhak untuk dipilih dan memilih, dipihak lain sebagian besar masyarakat masih ingin mempertahankan Demokrasi tradisional dengan tetap mempertahankan kondisi pelaksanaan pemilihan Raja atas usulan Matarumah Parentah. Pemilihan Raja sebagaimana Kebijakan Perda Nomor 3 Tahun 2006 adalah selain mengurangi ongkos politik juga mengeleminir konflik ditengah masyarakat.

5. Kepentingan Penguasa serta Sikap dan Perilaku Badan-Badan Pelaksana.

Cenderung memihak serta mengikuti keinginan penguasa adalah penyebab ketidakefektifan implementasi pelaksanaan pemilihan Raja di Kabupaten Maluku Tengah. Perilaku mengikuti kehendak penguasa yang masih terpatri hingga saat ini oleh BadanBadan Pelaksana seperti Camat, Pejabat Raja dan Saniri Negeri telah mengakar dan membudaya. Adanya keinginan untuk kembali memegang tampuk kekuasaan telah dinodai dengan melakukan cengkraman terhadap struktur birokrasi pada level bawah bahkan bila dimungkinkan melalui tindakan yang dapat menyingkirkan atau melepaskan jabatan seseorang dari kedudukannya.

6. Biasnya Sejarah Asal Usul \& Tradisi Tata Pemerintahan Adat.

Salah satu aspek yang sangat mempengaruhi ketidakefektifan pelaksanaan pemilihan Raja di Kecamatan Salahutu adalah ketidaktahuan masyarakat adat terhadap Sejarah dan asal usul tradisi dan Tata Pemerintahan Adat yang telah tergerus oleh perubahan zaman, dan politisasi demokrasi oleh penguasa selama puluhan tahun dan hilangnya beberapa generasi yang mengetahui kepastian sumber dan informasi tentang penyelenggaraan Tata Pemerintahan Adat dengan Struktur serta budaya Masyarakat Adat, sehingga mengakibatkan konflik diantara masyarakat adat.

\section{SIMPULAN}

Implementasi Kebijakan Pemilihan Kepala Pemerintahan Negeri di Kabupaten Maluku Tengah (Studi di Kecamatan Salahutu), berdasarkan hasil penelitian menunjukan belum efektif pelaksanaannya. Hal ini disebabkan karena beberapa faktor yang terindikasi sebagai pangkal permasalahan diantaranya adalah konflik keabsahan ahli waris Raja di antara marga/kelompok masyarakat adat, belum dirampungkannya Peraturan Negeri, ketiadaan atau kurangnya personil/SDM dari kelembagaan Saniri Negeri yang belum memadai dan mumpuni, ketidak konsistenan terhadap ketentuan dan aturan hukum oleh badan pelaksana/Saniri Negeri, dan biasnya informasi tentang asal usul Raja, 
serta hilangnya beberapa generasi yang mengetahui sejarah Tata Pemerintahan Negeri sebagai penyebab ketidakefektifan pelaksanaan pemilihan Raja di Kecamatan Salahutu. Selain faktor-faktor tersebut kondisi eksternal masyarakat adat yang telah terpolarisasi dengan mekanisme pemilihan di era Orde Baru sebagai penyebab ketidakefektifan pelaksanaan pemilihan Kepala Pemerintahan Negeri. Pada saat yang sama, masyarakat dengan tingkat pendidikan memadai serta berwawasan demokrasi modern menghendaki proses penetapan serta penyelenggaraan pemilihan Raja dilakukan secara transparan dengan menyertakan setiap warga negara yang telah memenuhi syarat, baik untuk dipilih dan memilih. Dilain pihak lain masyarakatpun menyambut baik kebijakan pemilihan Raja dengan sistem pengusulan oleh Matarumah Parentah untuk disampaikan kepada Bupati melalui Saniri Negeri. Proses pengusulan calon Raja oleh Matarumah sebagaimana implementasi Perda Nomor 3 Tahun 2006 adalah untuk menghindari biaya politik yang begitu mahal dan mengeleminir konflik sesama warga yang selama ini terjadi. Dengan dalih tidak mencampuri urusan adat istiadat dan kewenangan Negeri, Pemerintah Daerah Kabupaten Maluku Tengah terkesan membiarkan konflik Ahli Waris Raja cenderung tidak terselesaikan bahkan menjadi isu politik bagi kepentingan orang-orang tertentu termasuk Saniri Negeri untuk tidak menaati ketentuan dan aturan yang berlaku. Dari apa yang disampaikan tersebut, ternyata menurut peneliti variabel-variabel yang disampaikan Smith keseluruhannya belum efeltif dilaksanakan sehingga berakibat pada proses pelaksanaan pemilihan Kepala Pemerintahan Negeri.

\section{DAFTAR PUSTAKA}

Abidin, S.Z. (2004). Kebijakan Publik, Jakarta Pancar Siwah.

Karim, A.G. (2006). Komplesitas Persoalan Otonomi Daerah di Indonesia, Pustaka Pelajar, Jogjakarta.

Solichin, A.W. (2015). “Analisis Kebijakan, Jakarta, Bumi Aksara.

Agustino, L. (2016). "Dasar Dasar Kebijakan Publik, Bandung, Alfabeta.

Almond, G. \& Verba, S. (1963). The Civic Culture: Political Attitude and Democracy in Five Nations. Boston: Little, Brown and Company.

Amanullah, N. (2015). Demokratisasi Desa, Jakarta, Kementrian Desa Pembangunan Daerah Tertinggal dan Transmigrasi Republik Indonesia.

Anderson, J.E. (1990). Public Policymaking: An Introduction, Boston: Third Edition, USA, Penerbit, Houghton Miffin Company.

Arnstein. (1969). Eight Rungs on the Ladder Citizen Participation, Bandung: Alumni

Anggara, S. (2014). Kebijakan Publik, Bandung: Pustaka Setia.

Balai Penelitian Pers dan Pendapat Umum (BP3U), 1988, Analisis Isi Surat Kabar Isu Sentral Bulan Juni 1988 di D.I Jogyakarta dan Jawa Tengah: Pemilihan Kepala Desa, Laporan Penelitian: BP3U Deppen.

Bagir Manan dalam W. Riawan Tjandra dan Kresno Budi Harsono. (2009). Legal Drafting Teori dan Teknik Pembuatan Peraturan Daerah, Yogyakarta:Universitas Atmajaya, hlm. 25-28

Barret, G. \& Fudge, C. (1981). Policy and Action, London :Methuen

Rusli, B. (2015). Kebijakan Publik: Membangun Pelayanan Publik Yang Responsif, Bandung, CV. Adoya Mitra Sejahtera.

Creswell, J.W. (2015). Riset Pendidikan: Perancanaa, Pelaksanaan dan Evaluasi Riset Kualitatif dan Kuantitatif, Jogyakarta, Pustaka Pelajar.

Dewi, K.R. (2016). Studi Analisa Kebijakan, Bandung: CV. Pustaka Setia.

Hendri, D.D. (2016). Argumentasi Kebijakan Uji Publik Calon Kepala Daerah, Pustaka Kemang, Depok.

Dessler, G. (2003). Manajemen Sumber Daya Manusia. Jilid 2. Edisi Kesembilan. Jakarta: PT Indeks Kelompok Gramedia. 
Dye, T.R. (1992). Understanding Public Policy, 7th Ed New York: Prentice Hall.

Edwars, G.C. (1980). Implementing Public Policy, Washington. DC, Conggresional Quarterly Inc

Friedrich, C.J. (1969). Man And His Government, New York: McGraw-Hill

Goggin, M.I. Ann O’M Bowman, James P Lester, dan Laurence J.0 Toole,1990 Implementation theory and Practice; Toward a third Generation, New York: Harper Colins.

Grindle, M.S. (1980). Politics and Policy Implementation in The Third World, Princnton University Press, New Jersey.

Hadiz, V. (2005). Dinamika Kekuasaan: Ekonomi Politik Indonesia Pasca Soeharto, Jakarta, LP3ES.

He Baogang. (2014). "From Village Election to Village Deliberation in Rural China (Case Studi of a Deliberative), Journal of Chinese Political Science.

Islamy, M.I. (2003). Prinsip-prinsip Perumusan Kebijaksanaan Negara. Jakarta: Bumi Aksara.

Jenkins, W.I. (1978). Policy Analysis: A political and Organizational perspective, London: Martin Robertson.

Jones, C.O. (1984). An Introduction to the Study of Public Policy: Third Edition, Brooks/Cole Publishing Company, USA.

Kartodirjo, S. (1992). Sejarah Indonesia Baru. Jakarta: Gramedia Pustaka Utama.

Kooiman, J. (1999). Social Political Governance, Overview, Reflections and Design Public Management Review, Volume 1 No March.

Korten, D.C. (1988). Pembangunan Berdimensi Kerakyatan. Jakarta: Yayasan Obor Indonesia
Kurniawan, J.L. (2012). Perihal Negara Hukum \& Kebijakan Publik, Malang, Setara Press.

Kusuma, R. (2016). Studi Analisis Kebijakan. Bandung: Pustaka Setia.

Lester, J.P. \& Joseph Stewart, JR (2000). Public Policy : An Evolution Approach. Wadsworth.

Miles, M.B. \& A, Michael Huberman. (1992). Analisis Data Kualitatif. Jakarta: UI Press.

Smith, T.B. (1973). The Policy Implementation Process, Policy Sciencess 4, pp.197-209, Elsevier Scientific Publishing Company, Amsterdam-Printed in Scotland.

\section{Peraturan:}

Undang-Undang Dasar Negara Republik Indonesia Tahun 1945, Jakarta, Gramedia.

UU No 14 Tahun 1946, Tentang Perubahan Dalam STBLD No 212 Tentang Pemilihan Kepala Desa

UU No 6 Tahun 2014, Tentang Dana Desa.

UU No 23 Tahun 2014 Tentang Pemerintahan Daerah.

Peraturan Pemerintah No 72 Tahun 2005 Tentang Desa.

Perda No1 Tahun 2006, Tentang Negeri, Bagian Hukum Setda Kabupaten Maluku Tengah.

Perda No 3 Tahun 2006, Tentang Tata Cara Pemilihan Kepala Pemerintahan Negeri.Bagian Hukum Setda Kabupaten Maluku Tengah.

Perda No 4 Tahun 2006 Tentang Pedoman Penataan Saniri Negeri Atau Badan Permusyawaratan Negeri, Bagian Hukum Setda Kabupaten Maluku Tengah 